\title{
RANCIMAT TEST FOR MEASURING THE OXIDATIVE STABILITY OF COOKING OILS UPON PROLONGED FRYING: SHORT COMMUNICATION
}

\author{
AZMIL HAIZAM AHMAD TARMIZI*; KARIMAH AHMAD; MISKANDAR MAT SAHRI* \\ and CHOO YUEN MAY*
}

\begin{abstract}
The induction period or oxidative stability index (OSI) of four parent oils, i.e. palm olein (POo), soyabean oil (SBO), canola oil (CNO) and sunflower oil (SFO) was investigated and to be further compared with that of three binary blends of $P O O$ with $S B O, C N O$ and $S F O$, respectively and one tertiary blend of POo with $S B O$ and $C N O$. Two oil ratios of 90:10 and 50:50 were prepared for the binary blends of POo + SBO, $\mathrm{POo}+\mathrm{CNO}$ and $\mathrm{POo}+\mathrm{SFO}$ while 40:50:10 for $\mathrm{POo}+\mathrm{SBO}+\mathrm{CNO}$. All the oils were used to fry French fries at $180^{\circ} \mathrm{C}$ for a total of $72 \mathrm{hr}$ ( $8 \mathrm{hr}$ daily for nine days) of intermittent frying. The stability of the oil was quantified by using the Rancimat test following the AOCS Official Method Cd 12b-92. Incorporation of POo has generally improved the induction period of the unsaturated oils as compared to their unary forms. Indeed, POo and its blends gave higher induction period after frying for $24 \mathrm{hr}$. Irrespective of oil types, the induction period was relatively comparable towards the end of frying sessions. The rate of induction period reduction is likely influenced by the presence of tocotrienol homologues in POo and its blends.
\end{abstract}

Keywords: oxidative stability, parent oils, binary blends, tertiary blend, intermittent frying, Rancimat test.

Date received: 31 May 2016; Sent for revision: 6 June 2016; Received in final form: 4 September 2016; Accepted: 6 October 2016.

\section{INTRODUCTION}

Frying is one of the favourable methods for processing food. The process essentially requires heating the oil at high temperatures ranging from $150^{\circ} \mathrm{C}$ and $200^{\circ} \mathrm{C}$ with the aim to provide optimum condition to dehydrate food. Immersion of food into hot oil causes water vapour evolution, and subsequently some of the oil penetrates into the food structure (Aguilera and Gloria-Hernandez, 2000). Significant amount of oil absorbed into the fried food leads to the development of unique sensory attributes, such as texture, flavour, aroma and appearance that make the food more attractive

Malaysian Palm Oil Board, 6 Persiaran Institusi,

Bandar Baru Bangi, 43000 Kajang, Selangor, Malaysia.

E-mail: azmil_haizam@mpob.gov.my and palatable (Ahmad and Ismail, 2007). The simplicity, convenience and economic viability of this food processing technique contribute to promising demand of fried food.

Since frying oil is one of the key components in fried food, great attention must be paid to minimise oil quality loss during frying. It is a fact that such thermal treatment triggers a series of complex chemical reactions involving hydrolysis, oxidation and polymerisation that produce undesirable breakdown products and imparts off-flavour to the fried food (Zribi et al., 2014). Description on the reactions occurring during frying is summarised in Table 1. It is also important to note that these reactions can be more complicated when the breakdown products further interact with food residues. Other factors including fatty acid and food compositions also distinguish the extent of 
TABLE 1. CHEMICAL REACTIONS OCCURRING DURING FRYING

\begin{tabular}{lll}
\hline Reaction & \multicolumn{1}{c}{ Description } & Main constituents \\
\hline Hydrolysis & $\begin{array}{l}\text { Interaction between oil and water causes cleavage } \\
\text { of TAG bonds between glycerol and fatty acids }\end{array}$ & DAG, MAG, FFA \\
Oxidation & $\begin{array}{l}\text { Interaction of oil and oxygen by two reaction stages; } \\
\text { (1) primary oxidation - formation of hydroperoxides and }\end{array}$ & $\begin{array}{l}\text { Peroxides, aldehydes, alcohols, } \\
\text { hydrocarbons, FFA }\end{array}$ \\
Polymerisation & $\begin{array}{l}\text { Oxidation of the secondary oxidation constituents at } \\
\text { high temperature; and alteration of oil molecules or fatty } \\
\text { acids by heat resulted in the formation of large molecules }\end{array}$ & $\begin{array}{l}\text { Polymerised and oxidised TAG, } \\
\text { dimers, cyclic fatty acid monomers }\end{array}$ \\
\hline
\end{tabular}

Note: TAG - triacylglycerol; DAG - diacylglycerol; FFA - free fatty acid.

Source: Ahmad Tarmizi et al. (2016).

life span of the oil used for frying (Bensmira et al., 2007; Karoui et al., 2011).

Palm oil and particularly its liquid fraction that is palm olein $(\mathrm{POo})$ - has been proven as the most preferred oils used in various frying sectors, for instance domestic or household, fast food chains, mass catering and industrial frying (Matthäus, 2007). Versatility of palm oil as a frying medium is due to its techno-economic advantages over other traditional vegetable oils and therefore often regarded as a heavy-duty oil with higher resistance against thermal adulteration (Ahmad Tarmizi and Ismail, 2008; Nallusamy, 2006). Furthermore, consistency in the palm oil supply and attractive market price also encourage the use of this oil for various frying purposes.

Many publications have reported the performance of palm oil during heating and frying. Nonetheless, almost all of the studies performed are restricted to intermittent frying whilst published papers that emphasised on continuous frying are still inadequate. Higher cost associated to continuous frying trials and/or trade secret of the food processors for protecting their interest might be the reasons for this limitation (Ahmad Tarmizi and Ahmad, 2015; Ahmad Tarmizi and Ismail, 2014). It is also worth to note that these frying protocols have completely different procedures which affect the rate of oil breakdown and thus frying performance at different extent. The physico-chemical changes occurring in palm-based oils during heating and frying has been extensively reviewed by Ahmad Tarmizi et al. (2016).

Induction period or so called the oxidative stability index (OSI) is one of the methods used to examine the degree of oil to resist oxidation at elevated temperatures. Unlike peroxide and $p$-anisidine values - which provide static means of oil stability - induction period is a dynamic measurement which is able to provide an insight of oil providence during heating and frying (Aladedunye et al., 2014). The Rancimat test is commonly used for predicting the induction period of oil under heating condition. Nevertheless, this indicator is least preferred analysis for assessing oil stability during frying since published papers that quantified induction period as one of the oil quality indicators is less than a quarter (Ahmad Tarmizi and Ismail, 2008; 2014; Cardoso-Ugarte et al., 2013; Farhoosh et al., 2009).

Induction period can be expressed at various temperatures varying from $100^{\circ} \mathrm{C}$ to $130^{\circ} \mathrm{C}$. In the case of $\mathrm{POo}$, the induction period measured at $130^{\circ} \mathrm{C}, 110^{\circ} \mathrm{C}$ and $100^{\circ} \mathrm{C}$ are $13.7,24.2$ and 44.0 $\mathrm{hr}$, respectively (Berger, 2005). It appears that the induction period is more or less doubles for every increment of $10^{\circ} \mathrm{C}$. It is also established that the induction period decreases as a function of frying time; for example, the induction periods of 'Special Quality' and regular POo dropped from 25.5 to 17.5 $\mathrm{hr}$ and from 22.3 to $14.5 \mathrm{hr}$, respectively (Ahmad Tarmizi and Ismail, 2008).

The objective of this article is to evaluate the oxidative stability of $\mathrm{POo}$, soyabean oil (SBO), canola oil (CNO) and sunflower oil (SFO) as well as binary blends of POo with SBO, CNO and SFO, respectively and a tertiary blend containing $\mathrm{POo}$, SBO and CNO after $72 \mathrm{hr}$ of repeated frying. The results obtained by the Rancimat test would provide the indicative measure of oil stability with regards to induction period.

\section{MATERIALS AND METHODS}

\section{Materials}

Refined, bleached and deodorised (RBD) POo, $\mathrm{SBO}, \mathrm{CNO}$ and SFO were supplied by MOI Foods Ingredients Sdn Bhd, (Pulau Indah, Selangor, Malaysia). Pre-fried French fries were purchased from a local supplier (Ramly Food Processing Sdn Bhd, Kuala Lumpur, Malaysia). The composition of the oils used for frying is tabulated in Table 2. 
TABLE 2. COMPOSITION OF OILS USED FOR FRYING

\begin{tabular}{ll}
\hline Oils & Compositions \\
\hline Parent oils & \\
Palm olein (POo) & 100 \\
Soyabean oil (SBO) & 100 \\
$\quad$ Canola oil (CNO) & 100 \\
Sunflower oil (SFO) & 100 \\
Binary blends & \\
POo + SBO & $90: 10, \quad 50: 50$ \\
POo + CNO & $90: 10, \quad 50: 50$ \\
POo + SFO & $90: 10, \quad 50: 50$ \\
Tertiary blend & \\
POo + SBO + CNO & $40: 50: 10$ \\
\hline
\end{tabular}

\section{Frying Protocol}

Intermittent frying experiments were conducted using 23-litre capacity stainless steel electrical open fryer fitted with two split pots $(2 \times$ 11.5 litres); this frying system is similar with the one used by Ahmad Tarmizi and Ahmad (2015). The oil was first placed into the pots and heated to $180^{\circ} \mathrm{C}$ for $30 \mathrm{~min}$ prior to commissioning of frying session. For each pot, about $250 \mathrm{~g}$ of pre-fried French fries was fried for $3.5 \mathrm{~min}$ for every $30 \mathrm{~min}$ interval across $8 \mathrm{hr}$ per day for nine days. At the end of each day, 0.5 litre of used oil was sampled using a dark amber bottle, flushed with nitrogen and stored at $-20^{\circ} \mathrm{C}$ for subsequent analysis. The lids were placed on the pots and left overnight. In order to compensate for the amount of oil drawn out during sampling and oil absorbed by fried food, necessary amount of fresh oil was added into the fryers on the next day of frying operation to ensure constant level of 11.5 litres.

\section{Induction Period}

Induction period was measured using a 743 Rancimat (Metrohm, Herisau, Switzerland) at $110^{\circ} \mathrm{C}$ following the AOCS Official Method Cd 12b-92 (Firestone, 2009). About $0.3 \mathrm{~g}$ of oil sample was initially placed at the bottom of the reaction tube. The tubing from the air manifold was connected to the conductivity measurement tube. The aeration tube was then adjusted to within $5 \mathrm{~mm}$ from the bottom of the reaction and conductivity tube before measuring the air flow at $2.5 \pm 0.2 \mathrm{ml} \mathrm{s}^{-1}$. A plot of water conductivity versus time was profiled from a multi-channel strip chart recorder and the induction period reflection point was attest by a micro-processorcomputed slope algorithm. The induction period is defined as the point for which rapid changes as a result of oxidation, and expressed in hour (hr) (Aladedunye et al., 2014).

\section{Statistical Evaluation}

Two frying sessions were performed for each type of oils while the oil samples underwent for oxidative stability test in duplicate. One-way analysis of variance (ANOVA) was carried out using Minitab software to compare data obtained for different frying intervals and oil types. The differences were considered significant when $P<$ 0.05 at a confident level of $95 \%$. Arrangement of data for statistical analysis was performed by using Microsoft Office Excel 2007.

\section{RESULTS AND DISCUSSION}

The induction period of fresh POo was the highest $(28.1 \mathrm{hr})$, while all liquid oils displayed the values of no greater than $10 \mathrm{hr}$ : $6.3 \mathrm{hr}$ for SBO, $7.7 \mathrm{hr}$ for $\mathrm{CNO}$ and $4.6 \mathrm{hr}$ for SFO (Table 3). Addition of POo provides opportunity to enhance the oxidative stability of liquid oils. For instance, mixing 50\% and $90 \%$ POo in SBO has boosted the stability of the latter oil by $70 \%$ and $252 \%$, respectively (Table 4). Similar observation was also evidenced when $\mathrm{CNO}$ and SFO were blended with POo. Tertiary blend of POo with $\mathrm{SBO}$ and CNO gave an induction period of nearly $9 \mathrm{hr}$. Moreover, the results demonstrated that the induction period of fresh oil is predominantly correlated with the degree of saturation.

Results shown in Table 3 also demonstrate the decrease in the induction period in all oils for the first five days of frying was obvious before the values started to reach consistency until nine days of frying. The induction period of $\mathrm{PO}$ and blended oils containing 90\% POo fell sharply from their initial values when French fries were intermittently fried for over nine days as opposed to liquid oils; nevertheless, the values for palmbased oils were found to be higher for the first three days of frying (Table 3). This can be explained from the basis of significant level of tocotrienols in POo that constitutes more than $70 \%$ of the total vitamin $\mathrm{E}$ content. The presence of three double bonds at the side chain of tocotrienols makes them more susceptible to deterioration when exposed to excessive heat in comparison to their tocopherols counterpart (Aladedunye and Przybylski, 2014). Interestingly, a balance proportion of POo with $\mathrm{SBO}$ and $\mathrm{CNO}$, respectively and a tertiary blend containing $\mathrm{POo}, \mathrm{SBO}$ and $\mathrm{CNO}$ gave identical depreciation rate with that of their unary form; this however is not true for binary blend of $50 \%$ SFO. Despite the initial induction period of liquid oils were relatively lower, the oils were still capable to retain more than half of their initial values even after nine days of frying. It is also worth to mention that most vegetable 
TABLE 3. OXIDATIVE STABILITY OF PALM OLEIN (Poo), SOYABEAN OIL (SBO), CANOLA OIL (CNO) AND SUNFLOWER OIL (SFO) AND THEIR BLENDS AFTER NINE DAYS OF INTERMITTENT FRYING OF FRENCH FRIES

\begin{tabular}{|c|c|c|c|c|c|c|}
\hline \multirow[t]{2}{*}{ Oils } & \multicolumn{6}{|c|}{ Induction period $\left(\mathrm{hr}\right.$ at $\left.110^{\circ} \mathrm{C}\right)$} \\
\hline & Day 0 & Day 1 & Day 3 & Day 5 & Day 7 & Day 9 \\
\hline POo & $28.09 \pm 0.79 \mathrm{aA}$ & $14.45 \pm 0.49 \mathrm{bA}$ & $6.64 \pm 0.36 \mathrm{cA}$ & $3.93 \pm 0.01 \mathrm{dA}$ & $4.71 \pm 0.48 \mathrm{eAB}$ & $5.05 \pm 0.06 \mathrm{eA}$ \\
\hline SBO & $6.33 \pm 0.06 \mathrm{aB}$ & $4.19 \pm 0.14 \mathrm{bB}$ & $4.26 \pm 0.01 \mathrm{bB}$ & $3.76 \pm 0.12 \mathrm{cB}$ & $4.09 \pm 0.14 \mathrm{bA}$ & $3.79 \pm 0.02 \mathrm{cB}$ \\
\hline CNO & $7.71 \pm 0.12 \mathrm{aC}$ & $5.42 \pm 0.07 \mathrm{bC}$ & $4.93 \pm 0.08 c C$ & $4.11 \pm 0.12 \mathrm{dC}$ & $4.34 \pm 0.01 \mathrm{eB}$ & $4.06 \pm 0.04 \mathrm{dC}$ \\
\hline $\mathrm{SFO}$ & $4.64 \pm 0.09 \mathrm{aD}$ & $3.34 \pm 0.01 b D$ & $2.85 \pm 0.03 \mathrm{cD}$ & $2.38 \pm 0.08 \mathrm{dD}$ & $2.40 \pm 0.02 \mathrm{dC}$ & $2.56 \pm 0.16 \mathrm{dD}$ \\
\hline $90 \% \mathrm{POo}+10 \% \mathrm{SBO}$ & $21.78 \pm 0.21 \mathrm{aE}$ & $14.31 \pm 0.01 b A$ & $8.47 \pm 0.08 \mathrm{cE}$ & $5.05 \pm 0.13 \mathrm{dE}$ & $5.24 \pm 0.11 \mathrm{dD}$ & $5.68 \pm 0.07 \mathrm{eE}$ \\
\hline $90 \% \mathrm{POo}+10 \% \mathrm{CNO}$ & $22.27 \pm 0.69 \mathrm{aE}$ & $12.40 \pm 0.37 \mathrm{bE}$ & $7.78 \pm 0.00 \mathrm{cF}$ & $5.65 \pm 0.04 \mathrm{dF}$ & $4.82 \pm 0.13 \mathrm{eE}$ & $5.74 \pm 0.20 \mathrm{dE}$ \\
\hline $90 \%$ POo $+10 \%$ SFO & $17.95 \pm 0.01 \mathrm{aF}$ & $11.41 \pm 0.66 \mathrm{bE}$ & $5.23 \pm 0.15 c C$ & $3.70 \pm 0.01 \mathrm{~dB}$ & $3.60 \pm 0.01 \mathrm{eF}$ & $4.50 \pm 0.08 \mathrm{fF}$ \\
\hline $50 \%$ POo $+50 \%$ SBO & $10.75 \pm 0.01 \mathrm{aG}$ & $8.14 \pm 0.21 \mathrm{bF}$ & $6.87 \pm 0.16 \mathrm{cA}$ & $6.17 \pm 0.15 \mathrm{dG}$ & $5.83 \pm 0.08 \mathrm{eG}$ & $6.29 \pm 0.00 \mathrm{dG}$ \\
\hline $50 \% \mathrm{POo}+50 \% \mathrm{CNO}$ & $11.92 \pm 0.13 \mathrm{aH}$ & $9.93 \pm 0.09 b G$ & $8.56 \pm 0.76 \mathrm{cEF}$ & $5.74 \pm 0.29 \mathrm{dH}$ & $5.86 \pm 0.09 \mathrm{dG}$ & $6.53 \pm 0.08 \mathrm{eH}$ \\
\hline $50 \%$ POo $+50 \%$ SFO & $7.64 \pm 0.01 \mathrm{aC}$ & $5.26 \pm 0.12 b C$ & $3.89 \pm 0.09 \mathrm{cG}$ & $3.28 \pm 0.04 \mathrm{dI}$ & $3.23 \pm 0.06 \mathrm{dH}$ & $3.37 \pm 0.00 \mathrm{dI}$ \\
\hline $40 \% \mathrm{POo}+50 \% \mathrm{SBO}+10 \% \mathrm{CNO}$ & $8.72 \pm 0.08 \mathrm{aI}$ & $6.06 \pm 0.24 \mathrm{bH}$ & $5.28 \pm 0.13 c \mathrm{C}$ & $4.90 \pm 0.03 \mathrm{dE}$ & $4.62 \pm 0.04 \mathrm{eI}$ & $5.00 \pm 0.12 \mathrm{dA}$ \\
\hline
\end{tabular}

Note: Means within a row across frying times with the same lower case letters are insignificantly different $(P<0.05)$. Means within a column across oil types with the same upper case letters are insignificantly different $(P<0.05)$.

TABLE 4. COMPOSITION OF OILS USED FOR FRYING

\begin{tabular}{lc}
\hline Oils & $\begin{array}{c}\text { Depreciation of induction } \\
\text { period } \%\end{array}$ \\
\hline POo & 82 \\
SBO & 40 \\
$\mathrm{CNO}$ & 47 \\
$\mathrm{SFO}$ & 45 \\
$90 \% \mathrm{POo}+10 \% \mathrm{SBO}$ & 74 \\
$90 \% \mathrm{POo}+10 \% \mathrm{CNO}$ & 74 \\
$90 \% \mathrm{POo}+10 \% \mathrm{SFO}$ & 75 \\
$50 \% \mathrm{POo}+50 \% \mathrm{SBO}$ & 41 \\
$50 \% \mathrm{POo}+50 \% \mathrm{CNO}$ & 45 \\
$50 \% \mathrm{POo}+50 \% \mathrm{SFO}$ & 56 \\
$40 \% \mathrm{POo}+50 \% \mathrm{SBO}+10 \% \mathrm{CNO}$ & 43 \\
\hline
\end{tabular}

Note: POo - palm olein.

SBO - soyabean oil.

$\mathrm{CNO}$ - canola oil.

SFO - sunflower oil.

oils including $\mathrm{SBO}, \mathrm{CNO}$ and SFO only contain tocopherols which constitute the total vitamin $\mathrm{E}$ content (CODEX Alimentarius, 2001).

\section{CONCLUSION}

POo and its blends with soft oils namely SBO, CNO or SFO have greater induction period than in their pure form after $24 \mathrm{hr}$ of frying. Albeit POo and its blends exhibited more or less equivalent induction period at the end of frying operation, this indicator alone cannot be used to conclude the extent of thermal resistance. Quality indices such as fatty acids composition and polar compounds are also crucial and reliable means to describe the oxidative state of oils used for frying.

\section{ACKNOWLEDGEMENT}

The authors wish to thank the Director-General of MPOB, Director of Product Development and Advisory Services Division, Head of Protein and Food Technology Unit, and colleagues of Innovative Products Group for their support and technical assistance. The work was carried out with the funding from $\mathrm{MPOB}$ as part of their research activities.

\section{REFERENCES}

AGUILERA, J $\mathrm{M}$ and GLORIA-HERNÁNDEZ, $\mathrm{H}$ (2000). Oil absorption during frying of frozen parfried potatoes. J. Food Sci., 65(3):476-479. DOI: 10.1111/j.1365-2621.2000.tb16031.x.

AHMAD, K and ISMAIL, R (2007). Palm oil products in cooking and frying. $27^{\text {th }}$ Palm Oil Familiarization Programme. Kuala Lumpur, Malaysia.

AHMAD TARMIZI, A H and AHMAD, K (2015). Feasibility of continuous frying system to improve the quality indices of palm olein for the production of extruded product. J. Oleo Sci., 64(12): 1259-1266. DOI: $10.5650 /$ jos.ees. 15131.

AHMAD TARMIZI, A H and ISMAIL, R (2014). Use of pilot plant scale continuous fryer to simulate industrial production of potato chips: thermal properties of palm olein under continuous frying conditions. Food Sci. Nutr., 2(1): 28-38. DOI: 10.1002/ fsn3.76.

AHMAD TARMIZI, A H; ISMAIL, R and KUNTOM, A (2016). Effect of frying on the palm oil quality attributes - a review. J. Oil Palm Res. Vol. 28(2):143153. 
AHMAD TARMIZI, A H and ISMAIL, R (2008). Comparison of the frying stability of standard palm olein and special quality palm olein. J. Amer. Oil Chem. Soc., 85(3): 245-251. DOI: 10.1007/ s11746-0071184-8.

ALADEDUNYE, F; KERSTING, $\mathrm{H} \quad \mathrm{J}$ and MATTHÄUS, B (2014). Phenolic extract from wild rose hip with seed: composition, antioxidant capacity, and performance in canola oil. Eur. J. Lipid Sci. Technol., 116(8):1025-1034. DOI: 10.1002/ ejlt.201300255.

ALADEDUNYE, F and PRZYBYLSKI, R (2014). Performance of palm olein and modified rapeseed, sunflower, soybean oils in intermittent deep-frying. Eur. J. Lipid Sci. Technol., 116(2): 144-152. DOI: 10.1002/ ejlt.201300284.

BENSMIRA, M; JIANG, B; NSABIMANA, C and JIAN, T (2007). Effect of lavender and thyme incorporation in sunflower seed oil on its resistance to frying temperatures. Food Res. Int., 40(3): 341-346. DOI: 10.1016/j.foodres.2006.10.004.

BERGER, K G (2005). The Use of Palm Oil in Frying. Malaysian Palm Oil Promotion Council.

CARDOSO-UGARTE, G A; MORLÁN-PALMAS, C C and SOSA-MORALES, M E (2013). Effect of the additional of basil essential on the degradation of palm olein during repeated deep frying of French fries. J. Food Sci., 78(7): C978-C984. DOI: 10.1111/1750-3841.12166.
CODEX ALIMENTARIUS (2001). CODEX Standard for Named Vegetable Oils CX-STAN 210-1999. p. 11-25.

FARHOOSH, R; KENARI, R E and POORAZRANG, H (2009). Frying stability of canola oil blended with palm olein, olive and corn oils. J. Amer. Oil Chem. Soc., 86(1): 71-76. DOI: 10.1007/ s11746-008-1315-x.

FIRESTONE, D (2009). AOCS Method No. Cd 12b92. Official Methods and Recommended Practices of the $A O C S .6^{\text {th }}$ edn, AOCS Press, Champaign.

KAROUI, I K; DHIFI, W; JEMIA, $\mathrm{M}$ B and MARZOUK, B (2011). Thermal stability of corn oil flavoured with Thymus capitatus under heating and deep-frying conditions. J. Sci. Food Agric., 91(5): 927933. DOI: $10.1002 /$ jsfa.4267.

MATTHÄUS, B (2007). Use of palm oil for frying in comparison with other high-stability oils. Eur. J. Lipid Sci. Technol., 109(4): 400-409. DOI: 10.1002/ ejlt.200600294 10.1002/ ejlt.200600294.

NALLUSAMY, S (2006). The role of palm oil in the snack food industry. International Palm Oil Trade Fair and Seminar. Kuala Lumpur, Malaysia.

ZRIBI, A; JABEUR, H; ALADEDUNYE, F; REBAI, A; MATTHÄUS, B and BOUAZIZ, M (2014). Monitoring of quality stability characteristics and fatty acid compositions of refined olive and seed oils during repeated pan- and deep-frying using GC, FT-NIRS, and chemometrics. J. Agric. Food Chem., 62(42): 10357-10367. DOI: 10.1021/jf503146f. 